\section{ORIGINAL ARTICLE}

Kenan Tastan ${ }^{1}$

Eda Kuran ${ }^{1}$

\begin{abstract}
${ }^{1}$ Atatürk University School of Medicine, Department of Family Medicine, Erzurum, Turkey.
\end{abstract}

\title{
Perceptions of Family Medicine Assistants about Education Environment and Factors Affecting These Perceptions \\ ABSTRACT
}

Objective: In this study it is aimed to determine the educational environment perceptions of Family Medicine assistants (FMA) and affecting factors.

Methods: Postgraduate hospital educational environment measure (PHEEM) scale was applied to 160 FMAs, and total PHEEM score and subscale scores were calculated.

Results: Mean age was $28.6 \pm 2.9$ years and 105 participants $(65.6 \%)$ were female. 130 of the participants (81.3\%) selected Family Medicine training voluntarily About $53.1 \%$ of the participants declared that health service is more important than training in their department. The mean PHEEM score was $89.98 \pm 22.99$. It was found that 103 (64.4\%) of the participants were satisfied with their educational environment but thought that it would be developed, and $8(5 \%)$ of them thought that it was a very poor educational environment. The mean total PHEEM score and subscale scores were similar between the participants from different, and between genders $(p>0.05)$. The mean PHEEM score and the mean perceptions of social support score of the participants who wanted to be a FM voluntarily was significantly higher than that of the others $(\mathrm{p}=0.04$ and 0.014 respectively). The mean total PHEEM score and subscale scores of the participants who do not have difficulty in making researches and publishing scientific papers were significantly higher than that of the others $(\mathrm{p}>0.05)$.

Conclusions: It is necessary to inform FMAs adequately about the department before they make their choice, to conduct the education service in a balanced manner, and to give them an opportunity to participate researches

Keywords: Family Medicine Assistants, Postgraduate Hospital Educational Environment Measure

\section{Aile Hekimliği Asistanlarının Eğitim Ortamı ile İlgili Algıları ve Bu Algıları Etkileyen Faktörler ÖZET}

Amaç: Bu çalışmada aile hekimliği asistanlarının eğitim ortamı ile ilgili algılarının ve bu algıları etkileyen faktörlerin araştırılması amaçlanmıştır.

Gereç ve Yöntem: Toplam 160 aile hekimliği asistanına Mezuniyet Sonrası Hastane Eğitim Ortamı Ölçeği (MESHEÖ) uygulandı. Total MESHEÖ skoru ve alt ölçek skorları hesaplandi.

Bulgular: Katılımcıların ortalama yaşı $28.6 \pm 2.9$ y1l ve 105 (\%65.6) katılımcı kadın idi. Katılımcıların 130’u (\%81.3) Aile Hekimliği eğitimini gönüllü olarak seçmişti. Yine \%53.1'i merkezlerinde hasta hizmetinin eğitimden daha öncelikli olduğunu düşünüyordu. Ortalama MESHEÖ skoru 89.98 22.99 idi. Katılımcıların 103’ü (\%64.4) eğitim ortamlarının yeterli olduğunu ancak geliştirilmesi gerektiğini düşünürken, 8'I (\%5) eğitim ortamlarının yetersiz olduğunu düşünüyordu. Ortalama total MESHEÖ skoru ve alt ölçek skorları değişik merkezlerden olan katılımcılar arasında ve kadınlar ve erkekler arasında benzer idi. $(\mathrm{p}>0.05)$. Aile hekimliğini gönüllü olarak seçmiş olan katılımcıların ortalama total MESHEÖ skoru ve ortalama sosyal destek algı skoru diğerlerinden anlamlı düzeyde yüksekti (sırasıyla $p=0.04$ ve 0.014). Bilimsel araştırma ve yayın yapma konusunda güçlük çekmediğini düşünen katılımcıların ortalama total MESHEÖ skorları ve alt ölçek skorları diğerlerinden anlamlı derecede daha yüksek idi ( $\mathrm{p}>0.05$ )

Sonuç: Aile hekimliği uzmanlığı almak isteyen kişilere seçimlerini yapmadan önce bölüm hakkında yeterli bilgi verilmesi, eğitim hizmetlerinin hasta hizmetleri. karşısında daha dengeli uygulanması ve aile hekimliği asistanlarına bilimsel araştırmalara katılmaları konusunda daha fazla şans verilmelidir.

Anahtar Kelimeler: Aile Hekimliği Asistanları, Mezuniyet Sonrası Hastane Eğitim Ortamı Ölçeği 


\section{INTRODUCTION}

Medical doctors' satisfaction with their working environment is an important factor that affects their productivity. It's found only one study evaluating the degree of satisfaction of the Family Medicine Assistants with their educational environment from Turkey (1). Expansion of the Family Physician Specialty training in Turkey is a relatively new entity. In present study, we aimed to measure the degree of satisfaction of the Family Medicine Assistants with their educational environment, determine the factors that affect the degree of satisfaction, and thus to set some advices about the Family Medicine Specialist training in our country.

\section{MATERIAL AND METHODS}

This is a cross-sectional study.

All Family Medicine assistants from the university hospitals and Education-Research Hospitals formed the target population of the study. During the study period, there were approximately 1000 Family Medicine assistants in Turkey.

It was calculated that a total of 160 samples should be included into the study ( 80 from university and 80 from Education-Research Hospitals (2).

For this study, ethics committee approval was received from the ethics committee of Atatürk University Medical Studies Department Head.

Study Protocol: We reached to 160 Family Physician assistants from university hospitals and Education-Research Hospitals via electronic mails, and they were requested to fill the queries and the scale. For this study postgraduate hospital educational environment measure (PHEEM) was used. The original scale had been developed by Roff et al (3) from England. The scale had been translated to Turkish by Balcığlu et al (2) and its validity and reliability studies had been performed.

In order to determine the independent variables a query was added to the scale. The dependent variable was the perceptions of the Family Medicine assistants with their educational environment. The independent variables were the type of hospital, city, age, gender, year in assistantship, year in medicine, graduated medical faculty, whether he is working in his voluntary selected field etc. The query and the scale were delivered to the participants via electronic mails. The names of the participants were not requested for maintaining an objective participation possible.

Postgraduate hospital educational environment measure is a 40 -item scale. Roff et al (2) divided the 40 items under three sub-scales. Those are perceptions of role autonomy, perceptions of teaching and perceptions of social support. Participants were asked to indicate their agreement with each statement using a five-level likert-type scale, which went from 'strongly disagree' -0 to 'strongly agree' -4 . Higher levels of agreement were correlated with more beneficial educational environments.

The total score of the scale is being determined by the sum of the point $(2,3)$. The scale presented four items that featured negative statements (items 7, 8, 11 and 13); the scores for these items were inverted in order to calculate total score from the questionnaire.

When evaluated as whole, the total score of the PHEEM is 160 points. The total PHEEM scores and the scores of subscales were interpreted as depicted in Table 1.

Table 1. Interpretation of the scores

\begin{tabular}{ll}
\hline Domain & Interpretation of score \\
\hline Total score & 0-40: Very poor \\
& 41-80: Plenty of problems \\
& 81-120: More positive than \\
& negative but room for \\
& improvement \\
& 121-160: Excellent \\
Perceptions & 0-14: Very poor \\
of role & 15-28: A negative view of \\
autonomy & one's role \\
& 29-42: A more positive \\
& perception of one's job \\
& 43-56: Excellent perception of \\
& one's job \\
Perceptions & 0-15: Very poor quality \\
of teaching & 16-30: In need of retraining \\
& 31-45: Moving right direction \\
& 46-60: Model teachers \\
Perceptions & 0-11: Nonexistent \\
of social & 12-22: Not a pleasant place \\
support & 23-33: More pros than cons \\
& 34-44: Good support \\
\hline
\end{tabular}

Statistical Analysis: Data are analyzed by SPSS 22.0 statistical program. Number and percent values for categorical data and mean and standard deviation values for numerical data are presented. The consistency of numerical variables to normal variation is evaluated by Histogram graphic. For comparison of groups the Student $t$ test and oneway ANOVA was used. A p value of $<0.05$ is considered as statistically significant.

RESULTS

A total of 160 Family Physician assistants formed the study group. Of them $80(50 \%)$ were working in university hospitals, and $105(65.6 \%)$ were female. The mean age of the participants was $28.6 \pm 2.9$ years (range $24-44$ years).

Year in assistantship were one year in 49 $(30.6 \%)$, second year in $57(35.6 \%)$ and third year in $54(33.8 \%)$ of the participants. They were from 30 different hospitals. 
The earliest graduation date among participants was 1986 with one person $(0.6 \%)$. The largest group consisted of 2014 graduates $(n=34$, $21.3 \%$ ) people. The mean postgraduation time was $8.1 \pm 7.1$ years. Family Medicine assistantship was a voluntarily selected specialty for $130(81.3 \%)$ of the participants. The responses of the participants to the question of "What about the education and patient service balance in your department?" are given in Table 2.

Table 2. Evaluations about the education and patient service balance

\begin{tabular}{lll}
\hline What about the education and patient service balance in your department? & $\mathbf{N}$ \\
Education is more important & 19 & 11.9 \\
Patient service is more important & 85 & 53.1 \\
There is a balance & 52 & 32.5 \\
Others & 4 & 2.5 \\
Total & 160 & 100.0 \\
\hline
\end{tabular}

Of the participants, $54(33.8 \%)$ responded as "Yes" to the question of "Do you have any difficulty in performing research and making scientific publications".

The item 7 (There is racism in this post) had the lowest score in the scale. Nevertheless $29.4 \%$ of the participants feels presence of racism in his educational environment.

The item 16 (I have good collaboration with other doctors in my grade) had the highest score in the scale. The $71.9 \%$ of the participant shave a good collaboration with other doctors in his grade.

The mean PHEEM score was 89.98 \pm 22.99 . The mean scores of the sub-scales were 33.21 \pm 8.7 for perceptions of role autonomy, $30.41 \pm 10.7$ for perceptions of teaching and $26.23 \pm 6.01$ for perceptions of social support.

Depending on the total scale score, the educational environments were evaluated as more positive than negative but room for improvement by $103(64.4 \%)$, plenty of problems by $39(24.4 \%)$, excellent by $10(6.3 \%)$ and very poor by $8(5 \%)$ participants.

In terms of the perceptions of role autonomy, 96 participants $(60 \%)$ evaluated as a more positive perception of one's job, 39 (24.4\%) as a negative view of one's role, $22(13.8 \%)$ as excellent perception of one's job and 3 as $(1.9 \%)$ as very poor.

In terms of perceptions of teaching, 69 participants (43.1) evaluated as moving in the right direction, $59(36.9 \%)$ as in need of some retraining, $19(11.9 \%)$ as very poor quality and $13(8.1 \%)$ as model teachers.

In terms of perceptions of the social support evaluations of participants were as following; more pros than cons $(n=110,68.8 \%)$, not a pleasant place $(\mathrm{n}=27,16.9 \%)$, a good supportive environment $(\mathrm{n}=18,11.3 \%)$ and non-existent $(\mathrm{n}=5,3.1 \%)$.

The mean total PHEEM score was not statistically different between males and females $(p=0.447)$. Also means of perceptions of role autonomy score, perceptions of teaching score and perceptions of the social support score were similar between male and female assistants $(\mathrm{p}=0.612$; $\mathrm{p}=0.493 ; \mathrm{p}=0.777$, respectively) (Table 3 ).

The mean total PHEEM score of assistants who had voluntary selected his field was significantly higher than that of the others $(\mathrm{p}=0.04)$. Also the mean score for perceptions of social support was significantly higher among them $(p=0.014) \quad($ Table 3$)$. The highest total PHEEM score was from the males who had voluntarily selected his field, and the lowest was from the females who had involuntarily selected her field.

The mean total PHEEM score, perceptions of role autonomy score, perceptions of teaching score and the perceptions of social support score were significantly higher among assistants who do not have any difficulty in performing research and making scientific publications $(\mathrm{p}=0.000 ; \mathrm{p}=0.000$; $\mathrm{p}=0.000 ; \mathrm{p}=0.001$, respectively) (Table 3).

The mean values of total PHEEM and subscales' scores were not significantly different between the participants working in university hospitals and Ministry of Health hospitals. Also there was no significant differences in terms of the year of the assistantship (Table 3).

When the answers of the participants to the question of "What about the education and patient service balance in your department?" was evaluated, ANOVA test revealed a significant difference between the mean total scores of the responses $(p>0.05)$ (Tablo 3). The mean total PHEEM score of the responders as "There is a balance" was significantly higher than that the responders as "Education is more important" $(\mathrm{p}=0.001)$ and "Patient service is more important" $(p=0.008)$. The mean perceptions of teaching score of the resposders as "There is a balance" was significantly higher than that of the responders as "Patient service is more important" $(p=0.001)$. The mean perceptions of the social support score of the resposders as "There is a balance" was significantly higher than that of the responders as "Patient service is more important" $(\mathrm{p}=0.014)$ (Table 3$)$. 
Table 3. Mean total PHEEM and subscale scores for different groups.

\begin{tabular}{|c|c|c|c|c|}
\hline & PHEEM score & $\begin{array}{l}\text { Perceptions of } \\
\text { role autonomy }\end{array}$ & $\begin{array}{l}\text { Perceptions of } \\
\text { teaching }\end{array}$ & $\begin{array}{l}\text { Perfeptions of the } \\
\text { social support }\end{array}$ \\
\hline \multicolumn{5}{|l|}{ Gender } \\
\hline Female (105) & $88.97 \pm 22.841$ & $32.95 \pm 8.647$ & $29.99 \pm 10.811$ & $26.13 \pm 5.910$ \\
\hline Male (55) & $91.89 \pm 23.362$ & $33.69 \pm 8.890$ & $31.22 \pm 10.558$ & $26.42 \pm 6.259$ \\
\hline $\mathrm{p}$ & 0.447 & 0.612 & 0.493 & 0.777 \\
\hline \multicolumn{5}{|c|}{ Voluntarily selected his field } \\
\hline Yes (130) & $91.70 \pm 22.834$ & $33.72 \pm 8.582$ & $30.98 \pm 10.984$ & $26.79 \pm 5.812$ \\
\hline No (30) & $82.50 \pm 22.523$ & $31.00 \pm 9.067$ & $27.97 \pm 9.178$ & $23.80 \pm 6.365$ \\
\hline $\mathrm{p}$ & 0.04 & 0.12 & 0.16 & 0.014 \\
\hline Female Yes (83) & $91.17 \pm 21.783$ & $33.67 \pm 8.147$ & $30.88 \pm 10.879$ & $26.75 \pm 5.421$ \\
\hline Female No (22) & $80.68 \pm 25.293$ & $30.23 \pm 10.066$ & $26.64 \pm 10.088$ & $23.82 \pm 7.149$ \\
\hline $\mathrm{p}$ & 0.055 & 0.097 & 0.102 & 0.038 \\
\hline Male Yes (47) & $92.64 \pm 24.798$ & $33.79 \pm 9.392$ & $31.15 \pm 11.285$ & $26.87 \pm 6.506$ \\
\hline Male No (8) & $87.50 \pm 11.976$ & $33.13 \pm 5.436$ & $31.63 \pm 4.779$ & $23.75 \pm 3.808$ \\
\hline $\mathrm{p}$ & 0.570 & 0.848 & 0.907 & 0.195 \\
\hline \multicolumn{5}{|c|}{ Do you have any difficulty in performing research and making scientific publications } \\
\hline Yes (54) & $78.94 \pm 22.496$ & $29.87 \pm 8.616$ & $24.93 \pm 10.921$ & $23.96 \pm 6.127$ \\
\hline No $(106)$ & $95.59 \pm 21.223$ & $34.91 \pm 8.294$ & $33.21 \pm 9.489$ & $27.39 \pm 5.641$ \\
\hline $\mathrm{p}$ & 0.000 & 0.000 & 0.000 & 0.001 \\
\hline \multicolumn{5}{|l|}{ Training center } \\
\hline $\begin{array}{l}\text { Education-Research } \\
\text { Hospital (80) }\end{array}$ & $88.95 \pm 22.808$ & $32.76 \pm 8.981$ & $30.74 \pm 10.297$ & $25.84 \pm 5.725$ \\
\hline $\begin{array}{l}\text { University Hospital } \\
\text { (80) }\end{array}$ & $91.00 \pm 23.268$ & $33.65 \pm 8.465$ & $30.09 \pm 11.158$ & $26.63 \pm 6.301$ \\
\hline $\mathrm{p}$ & 0.574 & 0.521 & 0.702 & .409 \\
\hline \multicolumn{5}{|l|}{ Year in assistantship } \\
\hline First year (49) & $87.71 \pm 22.901$ & $32.27 \pm 8.592$ & $29.57 \pm 10.728$ & $26.14 \pm 6.535$ \\
\hline Second year (57) & $90.79 \pm 20.568$ & $33.28 \pm 8.351$ & $30.74 \pm 9.587$ & $26.39 \pm 5.460$ \\
\hline Third year (54) & $91.17 \pm 25.627$ & $33.98 \pm 9.254$ & $30.83 \pm 11.902$ & $26.15 \pm 6.187$ \\
\hline $\mathrm{p}$ & 0.574 & 0.521 & 0.702 & 0.409 \\
\hline \multicolumn{5}{|c|}{ What about the education and patient service balance in your department? } \\
\hline $\begin{array}{l}\text { Education is more } \\
\text { important (19) }\end{array}$ & $94.05 \pm 27.997$ & $35.26 \pm 10.744$ & $32.16 \pm 12.144$ & $27.16 \pm 6.710$ \\
\hline $\begin{array}{l}\text { Patient service is more } \\
\text { important (85) }\end{array}$ & $84.75 \pm 23.131$ & $31.74 \pm 8.493$ & $27.88 \pm 10.794$ & $25.14 \pm 6.240$ \\
\hline There is a balance (52) & $99.13 \pm 16.234$ & $35.40 \pm 7.285$ & $34.88 \pm 7.940$ & $28.25 \pm 4.635$ \\
\hline Others (4) & $62.50 \pm 22.576$ & $26.00 \pm 12.910$ & $17.75 \pm 9.811$ & $18.75 \pm 2.630$ \\
\hline $\mathrm{P}$ & $<0.05$ & $>0.05$ & $<0.05$ & $<0.05$ \\
\hline
\end{tabular}

\section{DISCUSSION}

Postgraduate hospital educational environment measure (3) had been used in a limited number of studies $(2,4,5)$ in order to evaluate the perceptions of the participants about their educational environments. The scale had been designed by Roff et al (3) from England, had been translated to Turkish by Balcığlu et al (2) and its validity and reliability studies had been performed.

Previous studies had been conducted on the speciality traners from different divisions $(2,4-6)$. We are aware of two studies, one from Turkey (2011) and the other from Saudia Arabia (2015), that had been conducted on the Familiy Medicine speciality trainers $(1,7)$. As some important changes (ie many new departments began to education, new regulations entered into force) in Familiy Medicine spesiality training occurred in Turkey, our study aimes to evalute the perceptions of the Family
Medicine speciality trainers about their educational environments under the new social environment.

In study of Khoja et al (7) the total PHEEM score had been reported as $67.1 \pm 20.1$, indicating a "Plenty of problems". Mean score for perceptions of role autonomy (24.2) indicated "a negative view of one's role", perceptions of teaching (25.3) indicated "in need of some retraining" and perceptions of social support (17.4) indicated "not a pleasant place". In our study the mean PHEEM score, and the means scores of subscales were all found to be higher (Table 3) from the Khoja et all's (7) study indicating a better educational environment in Turkey (2017).

In the study of Akdeniz et al (1), performed in 2011, the mean PHEEM score was 66 and indicated "Plenty of problems". In our study, it was $89.98 \pm 22.99$ and indicated a more positive level of 
perception, "more positive than negative but room for improvement".

In the study of Akdeniz et all (1), the mean score for perceptions of role autonomy had been reported as 26.4 (a negative view of one's role), for perceptions of teaching as 25.7 (in need of some retraining) and for perceptions of social support 18.7 (not a pleasant place). In our study theme an scores for the same subscales were33.21 18.7 (a more positive perception of one's job), $30.41 \pm 10.7$ (in need of some are training) and 26.23 \pm 6.01 (more pros than cons), respectively. Our results suggest that the perceptions of the Family Medicine speciality trainers about their educational environment had been increased during the last 6 years.

During the last 6 years, the importance of Familiy Medicine practice has inceased in our country as a result of the supports of the Ministry of Health. In addition, Education-Family Health Centers are opened, and family medicine realm training began to be performed in these centers. These emerging developments may have an important effect on the rised perceptions of role autonomy and social support. The increase in perceptions of teaching does not seem so high. In our country, Family Medicine is commonly perceived as a management unit rather than an educational unit. In addition, it is still academically less represented in hospitals. These may be the causes of the less increase in perceptions of teaching, as thought by Akdeniz et al (1).

Khoja et al (7) did not find a significant difference for the total mean PHEEM scores and the mean scores of the subscales between male and female participants. Only the mean PHEEM score of the females for item 13 (There is sex discrimination in this post) was significantly higher. This indicates a sex discrimination in Saudi Arabia. In our study there was not any significant difference between males and females in terms of the total PHEEM scores and the subscale scores.

Akdeniz et al (1) reported that for the most of the participants the Family Medicine training was not between their first 5 choices. Also, most of them had selected the Family Medicine as their point in the selection examination was enough for only this field. Whereas, in our study for the $81.3 \%$ of the participants Family Medicine was a voluntarily selected field. This finding indicates that Family Medicine training has become a more frequently voluntarily selected field for the doctors during the last 6 years. We think that, stabilization of the Family Medicine practice, increased education opportunities in the Education-Family Health Centersand increasing working opportunities in Family Health centers rather than the emergency departments with higher financial possibilities have important effects on this result.

Voluntarily selecting the the work field positively affects the PHEEM score. That has been shown by Balcioğlu et al (2). Probably this is the cause of the higher mean PHEEM score in our study than that of Akdeniz et al's (1). Also in present study, the mean PHEEM score of the participants who had voluntarily selected Family Medicine was significantly higher than that of the others. This finding indicates that voluntarily selecting the work field positively affects the educational envirenment perceptions of the Family Medicine traners. Mean score of perceptions of social support was significantly higher in traners who had voluntarily selected the field, however, mean scores of perceptions of role otonomy and perceptions of teaching were similar between two groups. In our study, the highest mean PHEEM score $(92.64 \pm 24.798)$ was found in the men who had voluntarily selected Family Medicine, and the lowest one $(80.68 \pm 25.293)$ in women who had unvoluntarily selected Family Medicine.

The mean PHEEM and subscale scores of the participants who had not difficulty in performing research and making scientific publications were significantly higher than that of participants who had. Balcıoğlu et al (2)] also find that the educational environment perception scores of the trainers' from different areas who had not difficulty in performing research and making scientific publications were significantly higher than that of trainers who had. Our finding suggests that the Family Medicine trainers have an expectation for joining to researches and making scientific publications.

The mean PHEEM and subscale scores of the participants from university hospitals and Education-Research Hospitals were not significantly different. This finding indicates that the educational opportunities are more important than the educational institution for the Family Medicine trainers in Turkey.

Both Balcıoğlu et al (2) and Khoja et al (7) found that the educational environment perception scores of the trainers increases by advancing year in fellowship. In our study, the mean PHEEM and subscale scores of the participants from first, second and third years in fellowship were similar (Tablo 3).

In Turkey, generally the work load of the Family Medicine traners does not change significantly during the educations years. For this reason, educational environment perception scores might not be affected from the year in fellowship.

Although all participants were from education hospitals, most of them feel that the patient service is more important than their education in their institutions. Also, the mean PHEEM scores of the participants who feels a balance between their education and patients service in their institution were significantly higher (Tablo 3). This finding suggests that the education centers of the Family Medicine traners should improve their educational conditions. 
In conclusion: The Family Medicine assistants think that the educational environment in Turkey is more positive than negative but room for improvement. So, the educational environment for the Family Medicine assistants should be supported, education and patient service must be balanced in these centers, the candidates should be informed previous to the examination in order to increase the number of the trainers who voluntarily select the specialty and the trainers should be supported in performing research and making scientific publications.

\section{REFERENCES}

1. Akdeniz M, Yaman H, Şenol Y, et al. Family practice in turkey: views of family practice residents. Postgrad Med 2011;123:144-9.

2. Balcıŏlu H. Tıpta uzmanlık öğrencilerinin eğitim ortamı algılamaları ve buna etkili faktörlerin değerlendirilmesi. Ankara: Ankara Üniversitesi 2008. (Thesis)

3. Roff S, McAleer S, Skinner A. Development and validation of an instrument to measure the postgraduate clinical learning and teaching educational environment for hospital-based junior doctors in the UK. Medical Teacher. 2005;27:326-31.

4. Clapham M, Wall D, Batchelor A. Educational environment in intensive care medicine - use of postgraduate hospital educational environment measure (pheem). Medical Teacher. 2007;29:e184-e91.

5. Boor K, Scheele F, Van der Vleuten CPM, Scherpbier AJJA, et al. Psychometric properties of an instrument to measure the clinical learning environment. Medical Education. 2007;41:92-9.

6. Aspegren K, Bastholt L, Bested KM, et al. Validation of the PHEEM instrument in a danish hospital setting. Medical Teacher. 2007;29:504-6.

7. Khoja AT. Evaluation of the educational environment of the saudi family medicine residency training program. J Family Community Med 2015;22:49. 